\title{
The Role of State Budget Expenditure on Economic Growth: Empirical Study in Vietnam
}

\author{
Hieu Huu NGUYEN ${ }^{1}$ \\ Received: June 2, 2019 Revised: June 15, 2019 Accepted: July 3, 2019
}

\begin{abstract}
Many authors have examined the impact of public spending on economic growth. This study uses ordinary least-squares technique to test the effect of state budget expenditure with two major components: development investment expenditure and recurrent expenditure on Vietnamese economy for the period 2000-2017. The empirical results show that the state budget expenditure of Vietnam has positive effect on the economy, however each main component has different impacts. Recurrent expenditure has significant positive impact on Vietnamese economy while there has no evidence to affirm the relationship between the development investment expenditure and the economic growth. Vietnamese government should restructure the state budget to enhance the positive effect on the economy. In the short run, Vietnam should not increase development investment expenditure due to low efficency in public investment. In the long run, it is necessary to economize recurrent expenditure to reserve a reasonable proportion of state budget for development investment expenditure to build infrastructure for developing the economy. The state budget expenditure should be restructured towards prioritizing recurrent expenditure on human and social relief, reducing public administration expenditure, allocating investment capital from the state budget for key and pervasive projects, avoiding spreading out investments as well as crowding out private investments.
\end{abstract}

Keywords: State Budget Expenditure, Development Investment Expenditure, Recurrent Expenditure, Gross Domestic Product (GDP).

JEL Classification Code: G38, H11, H50, O11.

\section{Introduction}

State budget expenditure is an important factor affecting the economic growth. Each component in the structure of state budget expenditure has different levels of influence on economic growth due to the difference in its nature and objective. The affirmation on whether the state budget expenditure impacts the economy or not and which component of the state budget expenditure has greater impact on the economy has an important implication for the government. Within a limited budget, the government can still achieve higher economic growth by reallocating expenditure towards prioritizing highly efficient components

1 First Author and Corresponding Author. Dean, Fundamental Faculty, Audit Training Institute, State Audit Office of Vietnam [Postal Address: 116 Nguyen Chanh Street, Cau Giay District, Hanoi, 100000 Vietnam].

Email: hieunh@sav.gov.vn and nguyenhuuhieuktnn@gmail.com

() Copyright: Korean Distribution Science Association (KODISA)

This is an Open Access article distributed under the terms of the Creative Commons Attribution NonCommercial License (https://creativecommons.org/licenses/by-nc/4.0/) which permits unrestricted noncommercial use, distribution, and reproduction in any medium, provided the original work is properly cited. while reducing low efficient ones to minimize the negative impact on the economy.

Vietnam now is an emerging country in Southeast Asia region. Thanks to the shift from a centrally-planned to a market economy, Vietnam has achieved a relatively high economic growth rate and become a lower middle-income country since 2010. GDP per capita was USD2,385 in year 2017. However, to overcome the middle-income trap, Vietnam needs to achieve and maintain an annual economic growth rate of $7.0 \sim 7.5 \%$ in the long run. The state budget expenditure is a tool of fiscal policy which is used by Vietnamese government in combination with state budget collection policy and monetary policy to drive the economy. The scale of Vietnam's state budget expenditure is large, in the range of $25 \sim 35 \%$ of GDP. Such a high spending level raises the necessity for an accurate assessment on the level of contribution of state budget expenditure to Vietnamese economic growth to form a basis for a more efficient policy planning and enforcement. The assessment on impact of state budget expenditure on the economy becomes more and more critical when Vietnam has faced difficulties in 
balancing the state budget in recent years since there is not much room to increase the revenue.

The purpose of this research is to analyze and evaluate the relationship between Vietnamese state budget expenditure, its main components (development investment expenditure and recurrent expenditure) and the economy. Does the state budget expenditure have positive impact on Vietnam's economic growth or not? Which expenditure is more significant to the economy, development investment expenditure or recurrent expenditure? Some recommendations on state budget expenditure restructuring are proposed therefrom.

\section{Literature Review}

The impact of government expenditures on economic growth is a topic that has been studied by many researchers. However, the results are still controversial. Keynes (1936) argued that the government must regulate aggregate demand through fiscal policy and monetary policy to have a higher level of employment. Keynes (1936) expected the government to have a greater responsibility to directly organize investments. He believed that the government expenditures, especially debt-financed expenditures, would increase aggregate demand thereby boosting economic growth.

Sharing the same opinions with Keynes (1936), Samuelson and Nordhaus (1948) from a macroeconomic point of view, highly appreciated the role of government in stimulating the economy. Government expenditure (G), together with private consumption expenditures (C), gross private domestic investment (I), and net exports (X), make up GDP. Samuelson and Nordhaus (1948) believed that government expenditures on certain goods or services (such as tanks, education, road construction, etc.) affect the overall level of spending of the economy and thereby influence the level of GDP. Mwafaq (2011) researched the relationship between government expenditure and economic growth in Jordan during the period 1990-2006. By testing the related data of government expenditures (recurring expenditures, development investment expenditures, transfer payment, and interest payment) and GDP of Jordan at the aggregate level, Mwafaq (2011) confirmed that the more the government spends, the better the growth of Jordanian economy is.

Burak and Timur (2002), in one of their researches, assumed that the economy consists of two distinct sectors, the government sector and the non-government sector. By employing panel data techniques and using data set for 34 developing countries for the period 1979-1997, they confirmed that government size seems to be an important factor influencing the economic growth. The total effect of government size on economic growth is positive and quite large. Mesghena (2011) used panel data from 26 SubSaharan African countries from 1987-1997 to examine the effect of government spending on economic growth. He confirmed that government spending, trade-openness, and private investment spending had positive and significant effect on economic growth. The offical development assistance and the growth rate in population were not statistically significant.

Constantinos (2009) had a similar result when studying the relationship between the economic growth and government spending of seven transition economies in South Eastern Europe. His research showed that government spending on capital formation, development assistance, private investment and trade-openness had positive impacts on economic growth. The remaining factor, population growth, was found to be statistically insignificant. Pula and Elshani (2018) based on Keynesian theories and endogenous growth model to examine the impact of public expenditure on economic growth of Kosovo from 2002 to 2015. They built a model in which GDP product used as a dependent variable and four independent variables: public expenditure, foreign direct investment, export and total budget revenue. The study results showed that public expenditure and export had a positive impact on economic growth. Total budget revenue was not proved to be statistically significant; foreign direct investment was negative and statistically insignificant.

Rahn (1986) admitted that government spending influences the economy, but the government spending is not always directly proportional to economic growth rate. Rahn, $\mathrm{R}$. introduced a model called "Rahn Curve" that reflected the relationship between public expenditure and economic growth. The Rahn Curve implied that public spending has a positive impact on economic growth when spending is moderate and allocated to public goods such as infrastructure, etc. but the impact will be reversed if public spending exceeds a certain threshold (Figure 1).

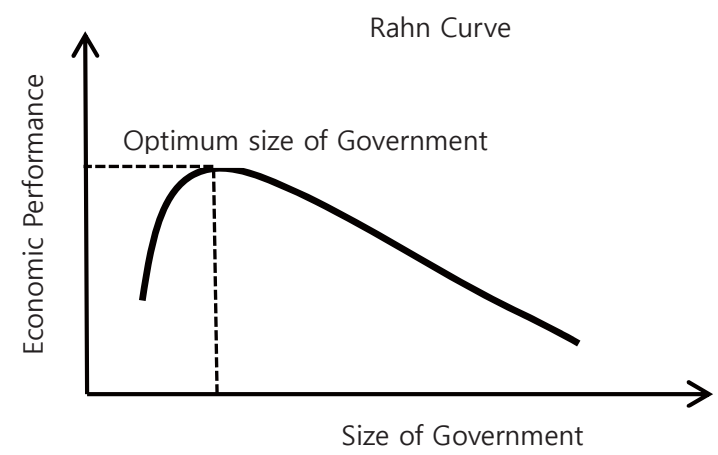

Source: Rahn (1986)

Figure 1: Rahn Curve 
The research of Rahn (1986) was further developed by Barro (1990). Barro (1990) was of the opinion that government spending has multi-dimensional effects on the economy. Assuming government spending is financed by taxes, the size of government which is the ratio of government spending to total revenue and tax rate has adverse effects on the economic growth. An increase in tax rates will reduce economic growth, but expansion in government spending will boost economic growth. Barro (1990) argued that normally when the government size is small, the impact of government spending is dominant, whereas when government size is large, the effect of taxes will overwhelm. This implies that government spending only promotes economic growth when the positive impact of spending increase is greater than the negative impact of tax increase.

Also, assuming that government spending is financed by tax, Chen (2006) affirmed that when the tax rate is higher than a specific threshold and the initial government spending is large, an increase in government spending will reduce the economic growth. However, if the initial government spending is under the threshold, an increase in government spending will speed up the economic growth. Hasnul (2015) researched the relationship between government expenditure and economic growth in the case of Malaysia. He drew an adverse conclusion that there was a negative correlation between government spending and Malaysian economy for the period 1970-2014. The researches of Kalu and Raphael (2016) also got the similar results. By using the ordinary least-squares regression techniques with series data in the period 1981-2013 in Nigeria, Kalu and Raphael (2016) confirmed that total government expenditure would not impact adequately on economic growth. There is a need for public - private partnership in funding and managing public projects.

Many scholars have studied deeply the relationship between the government spending and the economy through an analysis on the components of government spending. Nworji, Okwu, Obiwuru, and Nworji (2012) studied the effects of public expenditure on Nigerian economy for the period 1970-2009. They divided government expenditures into six components: capital and recurrent expenditures on economic services; capital and recurrent expenditures on social and community services; and capital and recurrent expenditures on transfers. The results showed that while capital and recurrent expenditures on economic services have negative effects on economic growth during the studied period, capital and recurrent expenditures on social and community services and capital and recurrent expenditures on transfers exert positive effects on economic growth.
Devarajan, Swaroop, and Zou (1996) focused on the relationship between components of government expenditures and economic growth in 43 developing countries from 1970 to 1990 . The results suggested that an increase in the share of recurrent expenditure has positive and statistically significant growth effects. By contrast, the relationship between the capital component of public expenditure and per-capita growth is negative. Devarajan et al. (1996) confirmed that developing-country governments had been misallocating public expenditures in favor of capital expenditures at the expense of recurrent expenditures. Sugata and Andros (2008) also got the same results when using panel data on 15 developing countries over 28 years (1972-1999) to examine the correlation between components of government expenditure and economic growth. The results showed that recurrent spending had positive and significant effects on the growth rate, while capital spending had negative effects. Tajudeen and Ismail (2013) analyzed the impact of public expenditure on economic growth in Nigeria during the period from 1970 to 2010. They divided public expenditures into capital and recurrent expenditure. Based on empirical results, this study suggested that total public spending would not stimulate Nigerian economic growth. The recurrent expenditure is found to have little positive impact on economic growth.

\section{Research Methodology and Results}

\subsection{Research Methodology}

This research is conducted to evaluate the impacts of state budget expenditure with two principal components: development investment expenditure and recurrent expenditure on Vietnamese economy. The author uses ordinary least-squares regression techniques facilitated by the application of the software for empirical econometric analysis, EViews 10. Variables that are put into the model are GDP as explained variable, development investment expenditure and recurrent expenditure as two explanatory variables. The model uses annual time-series data for the period 2000-2017 sourced from the Statistical Yearbook of Vietnam and Ministry of Finance of Vietnam. The model is expressed as follows:

$$
G D P=\beta_{1}+\beta_{2} D E V+\beta_{3} R E C+u
$$

where $\beta_{1}$ : Intercept of the regression line. It implies any level of economy at zero state budget expenditure. 
$\beta_{2}, \beta_{3}$ : Coefficients to be estimated. They measure the effects of development investment expenditure and recurrent expenditure on GDP, respectively.

DEV: Development investment expenditure.

REC: Recurrent expenditure.

$\mathrm{u}$ : stochastic variable to accommodate the influence of other determinants of economy not included in the model.

To assess the impacts of development investment expenditure and recurrent expenditure on GDP, the author also set up some hypotheses to test based on regression results. Statistical hypotheses which are set up for testing include whether population regression function is significant or not, whether each of variables DEV, REC has any effect on GDP or not.

\subsection{Empirical Results}

Using Eviews software, the GDP was regressed on the components of state budget expenditure (development investment expenditure and recurrent expenditure) and the results below obtained (Table 1 ):

Table 1: Empirical Results

\begin{tabular}{|c|c|c|c|c|}
\hline \multicolumn{5}{|c|}{ Dependent Variable: GDP } \\
\hline \multicolumn{5}{|c|}{ Method: Least Squares } \\
\hline \multicolumn{5}{|l|}{ Sample: 20002017} \\
\hline \multicolumn{5}{|c|}{ Included observations: 18} \\
\hline Variable & Coefficient & Std. Error & t-Statistic & Prob. \\
\hline C & 111306.9 & 52278.23 & 2.129126 & 0.0502 \\
\hline DEV & 0.071880 & 1.075988 & 0.066804 & 0.9476 \\
\hline REC & 5.231090 & 0.379085 & 13.79925 & 0.0000 \\
\hline R-squared & 0.996472 & \multicolumn{2}{|c|}{ Mean dependent var } & 2127494 . \\
\hline Adjusted R-squared & 0.996001 & \multicolumn{2}{|c|}{ S.D. dependent var } & 1576137. \\
\hline S.E. of regression & 99665.48 & \multicolumn{2}{|c|}{ Akaike info criterion } & 26.00804 \\
\hline Sum squared resid & $1.49 E+11$ & \multicolumn{2}{|c|}{ Schwarz criterion } & 26.15643 \\
\hline Log likelihood & -231.0723 & \multirow{2}{*}{\multicolumn{2}{|c|}{$\begin{array}{l}\text { Hannan-Quinn criter. } \\
\text { Durbin-Watson stat }\end{array}$}} & 26.02850 \\
\hline F-statistic & 2118.276 & & & 1.950937 \\
\hline Prob(F-statistic) & 0.000000 & & & \\
\hline
\end{tabular}

GDP = 111306.9 + 0.07188 DEV + 5.23109 REC

With the regression results obtained, statistical hypotheses are tested to have a more thorough assessment on the impact of state budget expenditure and its components on Vietnamese economy.

Hypothesis One: Whether the population regression function is significant or not

$\mathrm{H}_{0}: \mathrm{R}^{2}=0$ (The population regression function is not significant)
$\mathrm{H}_{1}: \mathrm{R}^{2} \neq 0$ (The population regression function is significant)

F-statistic is used to test. With number of observations (n)

$=18$, number of variables $(k)=3$, and significance level $(\alpha)$

$=0.05$, the result of $F$ is $2118.276>F_{\alpha}(k-1 ; n-k)=3.68$.

Based on above results, $H_{0}$ is rejected, therefore, $H_{1}$ is accepted. The significance of regression function shows that the state budget expenditure has significant positive effect on GDP. The regression results also indicate that independent variables included in the model (DEV and REC) explain about $99.6472 \%$ (R-squared $=0.996472)$ variations in the dependent variable (GDP).

Hypothesis Two: Whether DEV impacts GDP or not

$\mathrm{H}_{0}: \beta_{2}=0$ (DEV does not impact on GDP)

$\mathrm{H}_{1}: \beta_{2} \neq 0$ (DEV impacts on GDP)

T-statistic is used to test. With number of observations $(n)$ $=18$, number of variables $(\mathrm{k})=3$, and significance level $(\alpha)=$ 0.05 , the result of $\mathrm{T}$ is $0.066804<t_{\alpha / 2}^{(n-k)}=2.131$.

The above result indicates that $\mathrm{H}_{0}$ is not rejected. There is insufficient evidence to conclude that the explanatory variable DEV impacts on the explained variable, namely GDP.

Hypothesis Three: Whether REC impacts GDP or not.

$\mathrm{H}_{0}: \beta_{3}=0$ (REC does not impact on GDP)

$\mathrm{H}_{1}: \beta_{3} \neq 0$ (REC impacts on GDP)

T-statistic is used to test. With number of observations $(n)$ $=18$, number of variables $(\mathrm{k})=3$, and significance level $(\alpha)=$ 0.05 , the result of $\mathrm{T}$ is $13.79925>t_{\alpha / 2}^{(n-k)}=2.131$.

The result indicates that $\mathrm{H}_{0}$ is rejected, thereby confirming that explanatory variable REC has positive effect on explained variable GDP.

The above statistical hypothesis tests affirm that the state budget expenditure and recurrent expenditure have positive effect on the economy while the influence of development investment expenditure on the economy is invisible.

\section{Discussions}

Vietnam is a developing country with a low starting position. The scale of GDP in 2000 was at USD 31.17 billion. Thanks to high economic growth rate, averaging $6.76 \%$ in the period of 2000-2017, Vietnam's GDP in 2017 reached USD 223.78 billion, ranked 47th in the world. Vietnam has many potentials to develop and breakthrough (see Figure 2). With the model of socialist-oriented market economy, Vietnamese government plays an important role in promoting economic growth through two major tools: fiscal policy and monetary policy.

The state budget expenditure, an important component of fiscal policy, is monitored and implemented by Vietnamese 
goverment with disciplined, strict, and cost-effective orientation. State budget expenditure accounts for $30 \%$ GDP in the period 2000-2017. This proportion is much higher than the optimal government size which is about $15 \%$ GDP as proposed by Rahmayanti and Horn (2011) when performing empirical studies in 63 developing countries in the period 1990-2003. The average year-over-year increasing rate in Vietnamese state budget expenditure is about $16.7 \%$. This pace is also much higher than economic growth rate.

The results of regression and statistical tests show that state budget expenditure has a positive effect on GDP, in line with researches of Keynes (1936), Samuelson and Nordhaus (1948), Mwafaq (2011), Burak and Timur (2002), Mesghena (2011), Constantinos (2009), Pula and Elshani (2018), etc. This affirms the active role of Vietnamese government in regulating the economy to achieve the target of high and sustainable economic growth. However, the high level of state budget spending in Vietnam may create an adverse effect on the economy according to the research results of Rahn (1986), Chen (2006) and other economists. This is also in line with the basis economics theory. Government spending is mainly sourced from tax or loan. The increase of above funding sources will decrease the remaining financial resource of private sector and therefore, undermine the investment motivation from private sector.

Expenditure on development investment includes expenditure of state budget on execution of socio-economic infrastructure projects and projects serving socio-economic development and other investments as prescribed by law. Expenditure on development investment has been given a priority in Vietnam's fiscal policy. According to Law on State Budget, Vietnamese state budget is considered balanced if total revenue from taxes, fees, and charges is higher than recurrent expenditure and saving for development investment increases. Loans for covering the state budget deficit may only be used for development investment, not recurrent expenditure. The focus on investment expenditure is considered appropriate in the context that the infastructure of Vietnam such as roads, bridges, ports, etc. are insufficient and outdated, not being able to create favorable conditions for economic development. Vietnamese government has been applying the Public-Private Partnership model to attract private capital to participate in infrastructure development and public service provision projects. However, the mobility of financial resources has not been much. The current infrastructure construction projects mainly use state capital.

The investment capital allocated from the state budget has not been stable over the years and not followed any specific rules. The proportion of development investment expenditure in the total state budget expenditure in the period $2000-2017$ was about $27.6 \%$ on average, in which the ratio kept high in the period $2000-2012$, above $29-30 \%$; and highest in 2003 at $32.9 \%$. However, there was a sharp decrease in the period $2012-2016,24.8 \%$ on an average,

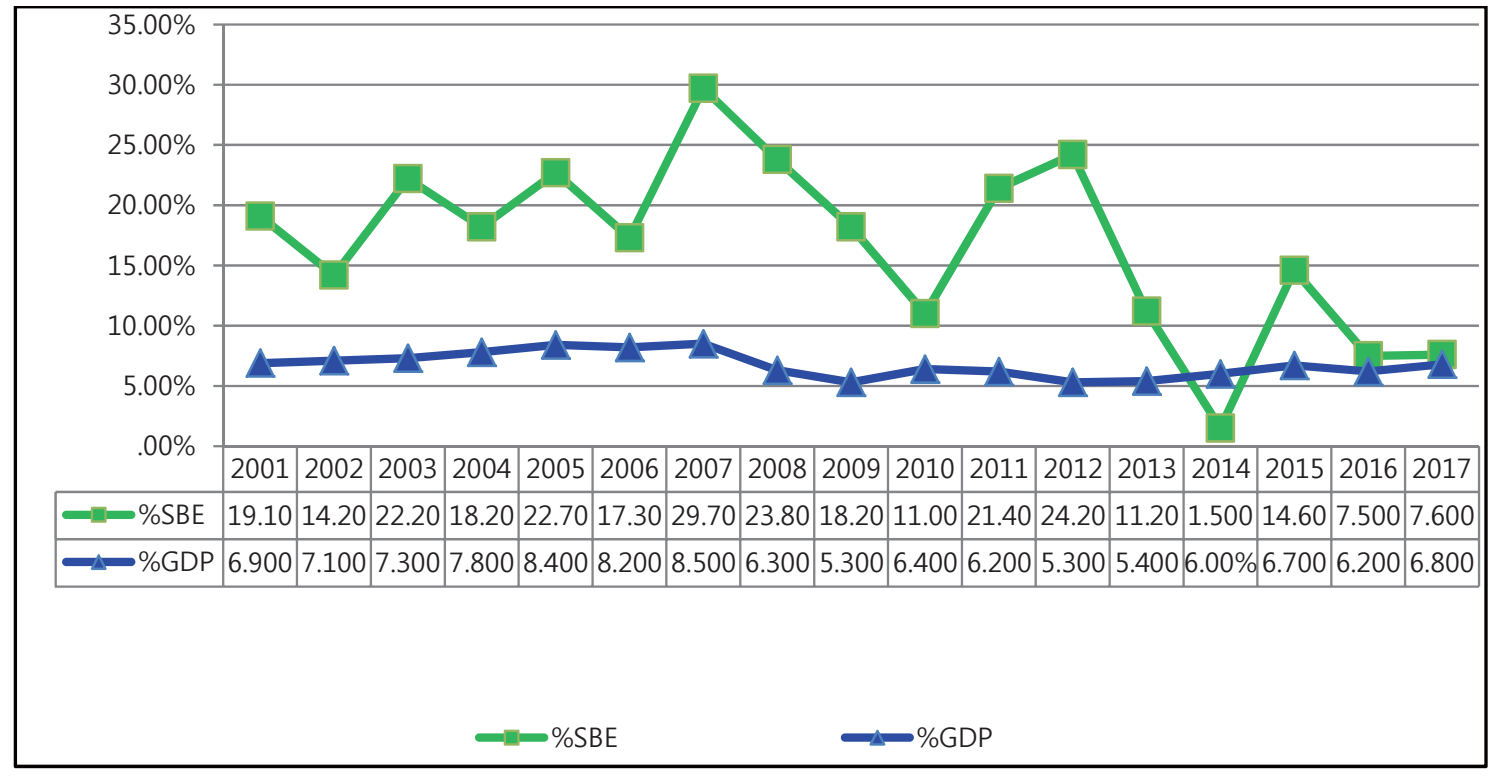

Source: General Statistics Office of Vietnam

"Note: - GDP(\%): Economic growth rate

- SBE(\%): State budget expenditure growth rate

Figure 2: The relationship between \%GDP and \%SBE 
especially $19.7 \%$ as the lowest rate in 2016 . The drop in state budget proportion on development investment expenditure in above periods can be explained by the following facts: i) Vietnamese economy which did not grow well with an averaged growth rate of $5.91 \%$ per annum led to the decrease of state budget collection; ii) the state budget deficit which exceeded the threshold of 5\% GDP (2012: 5.36\% GDP; 2013: 6.6\% GDP; 2014: 6.33\% GDP; 2015: 6.28\% GDP; and 2016: 5.52\% GDP) posed great pressure on the government in spending cut; and iii) the scale of public debt which increased rapidly (2012: $50.8 \%$ GDP; 2013: 54.5\% GDP; 2014: 58.0\% GDP; 2015: 61.0\% GDP; and 2016: 63.7\% GDP), and nearly reached the ceiling set by the National Assembly of Vietnam (65\% GDP) forced the government to reduce loan for investment.

In 2017, an increasing trend in the development investment expenditure was seen, accounting for $25.0 \%$ of the state budget expenditure. As the result of empirical study, the effect of development investment expenditure on the economy is invisible in the period 2000-2017 even though Vietnamese government supports the opinion on increase of development investment expenditure. This result is similar to the researches of Devarajan, Swaroop, and Zou (1996) and Sugata and Andros (2008). It implies that public investment is low efficient.

The low efficiency of public investment of Vietnam is explained by the following main causes:
Firstly, the investment capital from the state budget accounts for a large proportion of total investment capital and spreads out. The proportion of state sector investment in total investment capital tends to decrease but remains at a high level, with an average of $43.8 \%$ in the period 2000 2017 (see Figure 3). However, the crucial problem is that Vietnamese government has not identified the priority areas to receive investment capital from state budget. The government has allocated capital in many industries and sectors, some of which would be more efficient if invested by the private sector. Spreading out public investment therefore crowds out private investment.

Secondly, investment management is weak and negligent. Although Vietnam has put great efforts and achieved positive results in anti-corruption battle, the corruption in public investment projects has been worrying, mainly due to weak and loose management from both local and central authorities. Supervising and monitoring mechanism for the projects funded by state budget has not been strictly implemented with many loopholes which can be utilized by group interest.

Thirdly, loss and waste erode public investment. Loss reflects the situation that investment capital does not flow into the projects and does not constitute the value of the projects. Waste is the result of unnecessary investments. Loss and waste lead to undeniable fact that state investment has little impact on the economy. The loss and

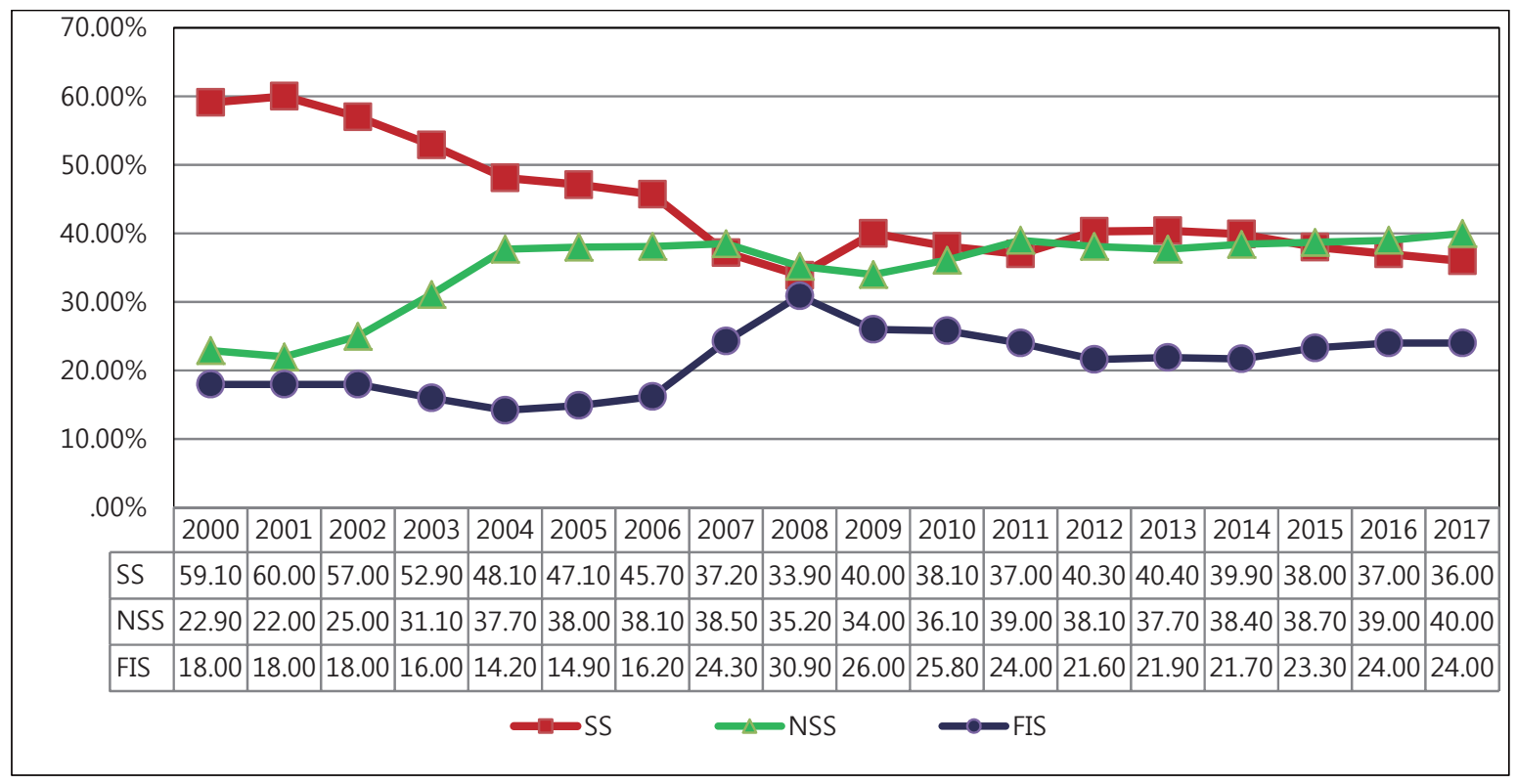

Source: General Statistics Office of Vietnam

NNote: - SS(\%): State sector

- NSS(\%): Non-state sector

- FIS(\%): Foreign investment sector

Figure 3: Total investment capital of Vietnam by types of ownership 
waste are closely connected with corruption, they create an unfavorable environment to meet the target on efficiency of Vietnam's public investment projects. If those limitations are not overcome, the more the state investment capital is, the more loss and waste will be.

Recurrent expenditure is obligatory expenditure of the state budget on maintenance of operation of the State apparatus, political organizations, socio-political organizations, support for operation of other organizations, and performance of regular tasks of the state in terms of socio-economic development such as education and training; healthcare; science and technology; culture, information, broadcasting, television and sports; social relief; economic services; environment protection; public administration etc. The recurrent expenditure is the largest expenditure of the state budget. The proportion of the recurrent expenditure in the state budget expenditure slightly declined in the period 2000-2005 but had increased rapidly since then, reaching the highest level in 2014 with the ratio of $65.5 \%$. The average ratio for the period $2000-$ 2017 was $56.9 \%$ (see Figure 4).
The recurrent expenditure is assessed as having positive effect on the economy of Vietnam. This empirical research is in line with the researches of Devarajan et al. (1996), Sugata and Andros (2008), Tajudeen and Ismail (2013) etc. Vietnamese government has implemented the principle of management and operation of recurrent expenditure in a tight and economic manner. The significant change in structure of expenditure which focuses on spending for education and training, healthcare, social relief has created a positive effect on economic development.

The scale of expenditure on education and training has increased, accounting for a large proportion of total recurrent expenditure, about $23 \%$. It implies the viewpoint and policy of Vietnam in which the education and training are considered as top national policy and given priority in using the state budget resources. Thanks to Vietnamese government's priority, achievement in education and training has a great milestone. Vietnam attained universal primary education in 2015 and has been moving towards universal lower secondary education. The percentage of literate population at 15 years of age and above is about $95.1 \%$. The quality of workforce therefore has been improving.

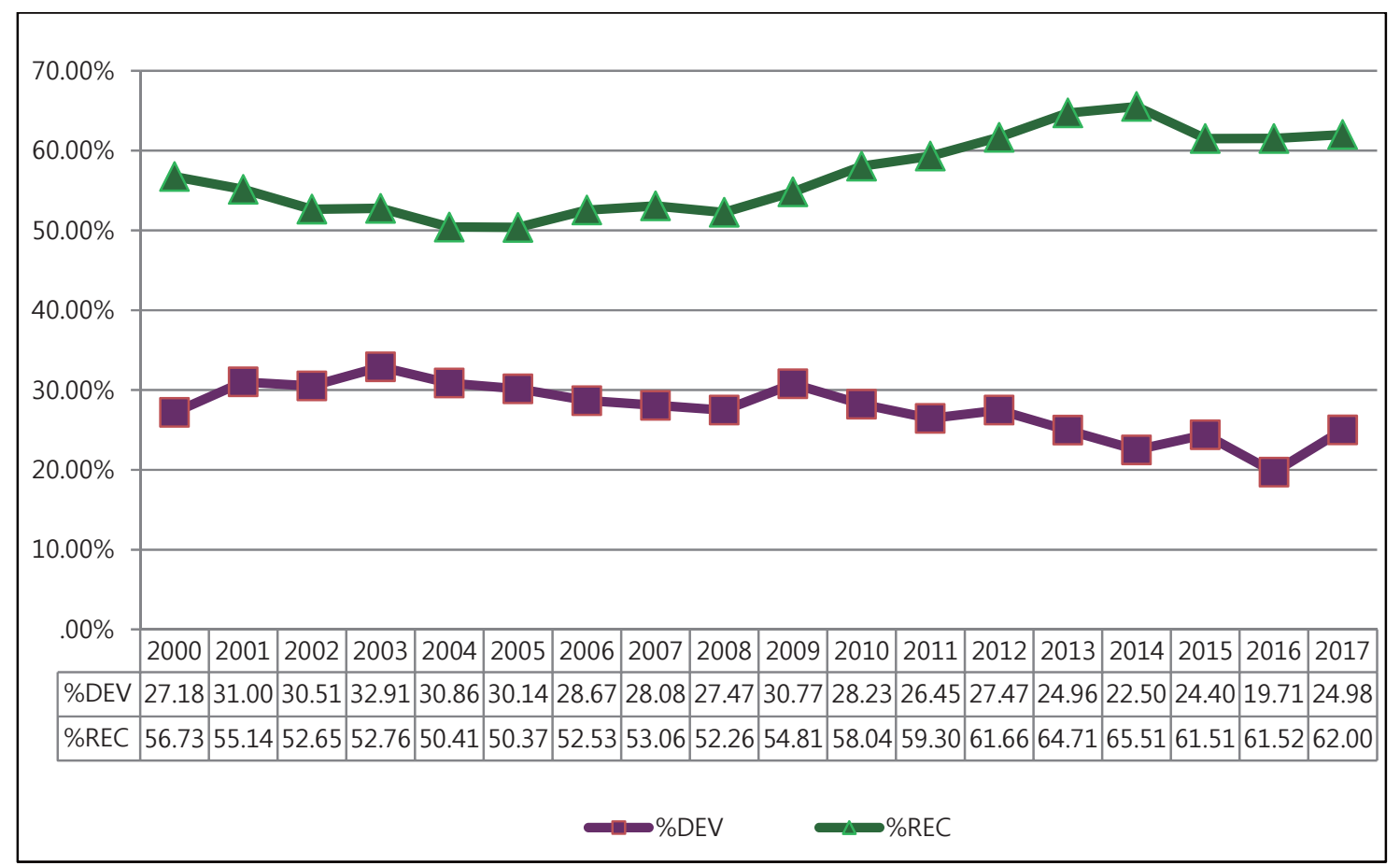

Source: General Statistics Office of Vietnam

"Note: - DEV(\%): Proportion of development investment expenditure over state budget expenditure

- REC(\%): Proportion of recurrent expenditure over state budget expenditure

Figure 4: The relationship between the proportion of development investment expenditure and recurrent expenditure over state budget expenditure 
Healthcare is also a sector that has been prioritized in receiving the state funding. Expenditure on healthcare increases significantly, about $6.8 \%$ of total recurrent expenditure on average. Together with education and training, the advancement of healthcare also helps improving the quality of human resources. Besides, total life expectancy at birth of Vietnam increased positively reaching 76.3 years in 2017 which gave Vietnam a world life expectancy ranking of 55 .

The state budget resources for maintenance, expansion and development of social security system are also focused and prioritized. Even in the years when state budget spending is reduced to restrain inflation but spending on social relief still increased, about $15.0 \%$ of total recurrent expenditure on average. Public investment on education and training, healthcare, social relief has formed a favourable platform for a rapid and sustainable growth of Vietnamese economy.

Nevertheless, expenditure on public administration is quite high in the structure of recurrent expenditure and accounts for a large proportion, averaging 14\%. The purpose of public administration expenditure is to ensure the operation of state apparatus. In Vietnam, the wages and salary paid for each civil servant are not high. However, due to the cumbersome organizational apparatus and excessive number of civil servants, the public administration expenditure is consequently high and increases continuously, reaching the highest rate at $17.1 \%$ of the recurrent expenditure in 2015 causing difficulties in state budget balancing.

\section{Conclusions and Recommendations}

\subsection{Conclusions}

This study uses ordinary least-squares regression techniques with time series data to evaluate the impacts of state budget expenditure and its main components on Vietnamese economy for the period 2000-2017. The results of empirical analysis show that the state budget expenditure of Vietnam has positive effect on the economy, however each major component has different impacts. Recurrent expenditure has significant positive influence on the economy, whereas the development investment is found to be statistically insignificant. This has given a warning on low efficiency in Vietnamese public investment. The state budget spending needs to be restructured to increase the positive effect on the economy.

\subsection{Recommendations}

To enhance the positive effect of state budget spending on the economy, the below recommendions are proposed to the policy makers:

Firstly, in the short run, Vietnam should not increase development investment expenditure. The current low efficiency in public investment will reduce the positive impact of the state budget expenditure on the economy if Vietnam keeps increasing capital from the state budget for the development investment. In the long term, in parallel with improvement of public investment efficiency, the recurrent expenditure should be economized to allocate reasonable resources in building infrastructure for developing the economy.

Secondly, development investment expenditure needs to be restructured based on clear definition of the role and function of the State and the market to avoid crowding out private investment. The loss and waste in public investment needs to be reduced through concentrating investment capital on key and pervasive projects as well as projects relating to settlement of issues on the development of the country, regions and inter-regions. The effectiveness of anticorruption in public investment needs to be enhanced. At the same time, Vietnamese government needs to promote private investment, encourage and facilitate private investors to participate in implementation of infrastructure construction projects.

Thirdly, recurrent expenditure needs to be restructured towards prioritizing spending on human (education, training, healthcare, etc.) and social relief systems to create a foundation for sustainable economic growth; reducing spending on public administration based on rearrangement of the state management apparatus, reduction of the civil servant and adoption of thrift practice and anti-waste measures.

\section{References}

Barro, R. J. (1990). Government Spending in a Simple Model of Endogeneous Growth. Journal of Political Economy, 98(S5), 103-125.

Burak, G., \& Timur, H. G. (2002). Government Expenditures and Economic Growth in Developing Countries: Evidence from a Panel Data Analysis. METU Studies in Development, 29(3-4), 311-332.

Chen, B.-L. (2006). Economic Growth with an Optimal Pulic Spending Composition. Oxford Economic Papers, 58, 123-136. 
Constantinos, A. (2009). Government Spending and Economic Growth: Econometric Evidence from the South Eastern Europe (SEE). Journal of Economic and Social Research, 11(1), 1-16.

Devarajan, S., Swaroop, V., \& Zou, H. (1996). The Composition of Public Expenditure and Economic Growth. Journal of Monetary Economics, 37, 313-344.

Kalu, I. A., \& Raphael, O. M. (2016). An Empirical Analysis of the Effect of Government Expenditure on Economic Growth in Nigeria (1981-2013). Research Journal of Finance and Accounting, 7(20). Retrieved from https://pdfs.semanticscholar.org/e82d/5441e92d4f07388b e863c141e824025b3395.pdf

Hasnul, A. G. (2015). The Effects of Government Expenditure on Economic Growth: the Case of Malaysia (MPRA Paper No. 71254).

Keynes, J. M. (1936). The General Theory of Employment, Interest, and Money. London, United Kingdom: Macmillan Publishing.

Mesghena, Y. (2011). Public Spending and Economic Growth: Empirical Investigation of Sub-Saharan Africa. Southwestern Economic Review, 30, 59-68.

Mwafaq, M. D. (2011). Government Expenditures and Economic Growth in Jordan. Paper presented at International Conference on Economics and Finance Research (vol.4). Singapore: IACSIT Press.

Nworji, I. D., Okwu, A. T., Obiwuru T. C., \& Nworji, L. O. (2012). Effects of Public Expenditure on Economic
Growth in Nigeria: A Disaggregated Time Series Analysis. International Journal of Management Sciences and Business Research, 1(7). Retrieved from http://www.ijmsbr.com/Volume\%201,Issue $\% 207 \% 20(6) \%$ 20Andy.pdf

Pula, L., \& Elshani, A. (2018). Role of Public Expenditure in Economic Growth: Econometric Evidence from Kosovo 2002-2015. Baltic Journal of Real Estate Economics and Construction Management, 6, 74-87.

Samuelson, P. A., \& Nordhaus, W. D. (1948). Economics (16th ed.). New York, NY: McGraw-Hill Companies.

Rahmayanti, Y., \& Horn, T. (2011). Expenditure Efficiency and the Optimal Size of Government in Developing Countries. Global Economy and Finance Journal, 4(2), 46-59.

Ram, R. (1986). Government Size and Economic Growth: A New Framework and Some Evidence from CrossSectional and Time-Series Data. American Economic Review, 76, 191-203.

Sugata, G., \& Andros, G. (2008). The Composition of Government Spending and Growth: Is Current or Capital Spending Better? Oxford Economic Papers, 60, 484-516.

Tajudeen, E., \& Ismail, O. F. (2013). Public Expenditure and Economic Growth in Nigeria: Evidence from AutoRegressive Distributed Lag Specification. Zagreb International Review of Economics \& Business, 16(1), 7992. 